\title{
The spatial distribution of leaf galls of Mikiola fagi (Diptera: Cecidomyiidae) and Neuroterus quercusbaccarum (Hymenoptera: Cynipidae) in the canopy of a Central European mixed forest
}

\author{
Christian KAMPICHLER* and MARKUS TESCHNER
}

Institute of Biology of the Free University Berlin, Soil Zoology and Ecology Laboratory, Grunewaldstrasse 34, D-12165 Berlin; e-mail: kampichl@zedat.fu-berlin.de

Key words. Mikiola fagi, Neuroterus quercusbaccarum, galls, spatial distribution, host preference, canopy, oak, beech

\begin{abstract}
Despite their wide distribution and frequent occurrence, the spatial distribution patterns of the well-known gall-inducing insects Mikiola fagi (Hartig) and Neuroterus quercusbaccarum (L.) in the canopies of mature trees are poorly described. We made use of the Swiss Canopy Crane (SCC) near Basel, Switzerland, to gain access to the canopy of a mixed temperate forest up to a height of $35 \mathrm{~m}$. Within one and a half days we scanned 6,750 beech leaves and 6,000 oak leaves. $M$. fagi showed a distinct vertical zonation with highest abundance in the top-most parts of the canopy as well as a significant aggregation on particular trees. $N$. quercusbaccarum showed an even more pronounced preference for particular trees and a general preference for Quercus robur over $Q$. petraea. In contrast to $M$. fagi, no vertical zonation could be detected. We think that both gall-inducing species have greater powers of dispersal than formerly assumed since they overwinter on the forest floor and yet are able to 1) gain access to the entire canopy, 2) show preference for certain host trees. We found little evidence for the phenological synchrony hypothesis proposed to explain the intertree distribution of $N$. quercusbaccarum. The highest density of $M$. fagi galls was in those parts of the canopy exposed to high solar radiation; their host choice is probably determined by micro-climatological factors. The consequences of the distribution patterns of $N$. quercusbaccarum and $M$. fagi for their ecological interactions with the host-plant, inquilines and parasitoids (e.g., canopy-layer specific performance linked to plant chemistry, density-dependent parasitism) need now to be subjected to further scientific investigation.
\end{abstract}

\section{INTRODUCTION}

Plant galls are conspicuous biological objects that have attracted the attention of mankind since early days: for more than 1000 years galls have been used in medicine, industry and even as human food in the Far East and many parts of Europe, and the earliest scientific interest in the 17 th century from the great Italian zoologist, M. Malpighi (Mani, 1992). Among the most common cecidia on leaves in Europe are the spangle galls on oaks, induced by species of the genus Neuroterus Hartig, 1840 (Hymenoptera: Cynipidae), and the galls on beech, Fagus sylvatica Linnaeus (1753), induced by Mikiola fagi (Hartig, 1839) (Diptera: Cecidomyiidae). Despite their wide distribution, frequent occurrence, high abundance and conspicuousness, and ecology being defined as the "scientific study of (...) the distribution and abundance of organisms" (Krebs, 1994) certain aspects of the spatial distribution of these galls on their host trees have been neglected. While there is some information on the between-tree distribution of Neuroterus spp. (e.g., Askew, 1962; Rosenthal \& Koehler, 1971), little is known of their spatial zonation in the canopies of mature forests. According to Hough (1953) young oak bushes and suckers at the bases of mature trees are usually more heavily galled than mature oak trees, but he gives no information on the distribution of galls on large trees. Askew $(1962,1984)$ and Ejlersen (1978) reported small- scale spatial patterns of spangle galls on leaves and branches of Quercus robur Linnaeus (1753). They also identified vertical distribution patterns in the canopy; the trees they investigated, however, were young oaks with a maximum height of $2.5 \mathrm{~m}$. So far, the only data for more mature trees comes from Rosenthal \& Koehler (1971): they determined spangle gall numbers up to a height of ca. $13 \mathrm{~m}$. There is even less data on the distribution patterns of $M$. fagi. Comprehensive entomological compendia such as those of Brauns (1991) and Honomichl (1998) contain no distributional information, and other authors only report very vaguely on the spatial patterns without reference to original data-sources, for example, Skuhravý \& Skuhravá (1996): "Since the larvae hibernate in their galls at the soil, the infestation of the lower branches is always higher than in the canopy." We are not aware of any data on the inter-tree distribution of M. fagi.

We think that this ignorance of the basic ecological spatial patterns of widespread and common gall-formers results from the limited possibilities for collecting data on galls from tree crowns. To gain access to the canopy one needs to erect towers, canopy walkways and cranes, or operate canopy-rafts (Bassett et al., 1997; Stork et al., 1997). Since 1999, the Swiss Canopy Crane (SCC) near Basel, Switzerland, has provided a unique opportunity for investigating canopy-scale spatial patterns in a mature temperate deciduous forest. Thus, the aim of this study was to analyse the distribution of the dominant leaf galls

\footnotetext{
* Corresponding author.
} 
TABLE 1. Mean numbers per sample unit (150 terminal leaves on three branches) of galls of Mikiola fagi and Neuroterus quercusbaccarum on Fagus sylvatica and Quercus robur and $Q$. petraea, respectively, at the Swiss Canopy Crane site near Basel. $n$ - number of sample units.

\begin{tabular}{lccc}
\hline Species & Canopy layer & $n$ & Mean no. of galls \\
\hline$M$. fagi & $>30 \mathrm{~m}$ & 13 & 125.1 \\
& $20-30 \mathrm{~m}$ & 11 & 85.5 \\
& $10-20 \mathrm{~m}$ & 13 & 42.0 \\
& $0-10 \mathrm{~m}$ & 8 & 37.5 \\
N. quercusbaccarum & $>30 \mathrm{~m}$ & 13 & 46.8 \\
& $20-30 \mathrm{~m}$ & 8 & 35.7 \\
& $10-20 \mathrm{~m}$ & 13 & 48.0 \\
& $0-10 \mathrm{~m}$ & 5 & 30.3 \\
\hline
\end{tabular}

at the SCC site, namely the galls of $M$. fagi and Neuroterus quercusbaccarum (Linnaeus, 1758); we were not interested in spatial scales at the level of leaf or branch but focussed on differences in gall abundance between the vertical layers of the canopy and between trees of the same genus.

\section{MATERIAL AND METHODS}

Neuroterus quercusbaccarum is a bivoltine cynipid species (subfamily Cynipinae Hartig) with one sexual and one agamic generation per year (Askew, 1984). Parthenogenetic females that emerge from spangle galls [syn. Neuroterus lenticularis (Olivier, 1791)] on the ground in spring oviposit in oak buds and induce the formation of currant galls on young leaves and male catkins. After a few weeks both sexes hatch from these galls, and the fertilised females lay eggs on oak leaves, which hatch to give larvae that cause the development of spangle galls that subsequently fall to the ground in late summer/early autumn. The larvae overwinter in the galls. The beech gall midge, Mikiola fagi, is univoltine and also overwinters in the galls on the ground. It emerges from the galls in early spring before budburst of its specific host, Fagus sylvatica. They oviposit close to the leafbuds. The larvae attack the leaf bases and induce conspicuous galls of considerable size (ca. 7-9 mm height) on the upper surface of the leaves (Urban, 2000), which are shed to the ground shortly before leaf fall.

The study site is located $12 \mathrm{~km}$ south of Basel, Switzerland $\left(47^{\circ} 28^{\prime} \mathrm{N}, 7^{\circ} 30^{\prime} \mathrm{E}\right)$ at an elevation of $550 \mathrm{~m}$. The climate is typical of a western European humid temperate zone climate, characterised by mild winters and moderately warm summers Mean annual temperature is $10.0^{\circ} \mathrm{C}$ (with mean January and July air temperatures of 2.1 and $19.1^{\circ} \mathrm{C}$, respectively), total annual precipitation is $990 \mathrm{~mm}$, and evapotranspiration averages $550 \mathrm{~mm}$. Soils are a silty loam of the rendzina type on a calcareous bedrock; profile depth is $30 \mathrm{~cm}$ with a $\mathrm{pH}$ of 5.8 in the top $10 \mathrm{~cm}$.

The forest is 80 to 120 years old, with tree heights between 30 and $36 \mathrm{~m}$, a tree density of 415 trees $^{-1} \mathrm{a}^{-1}$ (tree diameter $\geq 0.1$ $\mathrm{m})$, a total basal stem area of $46 \mathrm{~m}^{2} \mathrm{ha}^{-1}$ and a leaf area index of approximately $5 \mathrm{~m}^{2} \mathrm{~m}^{-2}$. It is dominated by European beech (Fagus sylvatica Linnaeus) and Sessile oak (Quercus petraea (Mattuschka) Lieblein), with English oak (Quercus robur Linnaeus), lime (Tilia platyphyllos Scopoli), hornbeam (Carpimus betulus Linnaeus), maple (Acer campestris Linnaeus), wild cherry (Prunus avium Linnaeus) and silver fir (Abies alba Miller) subdominant. In addition to these naturally regenerating species, there is an abundance of European larch (Larix decidua Miller), Norway spruce (Picea abies (Linnaeus) Karsten) and
Scots pine (Pinus sylvestris Linnaeus), which were established in the 19th century. The growing season of the deciduous species lasts for approximately 165 days, from the end of April to early October.

The Swiss Canopy Crane (SCC) was erected in March 1999 by lowering it from a helicopter into a natural gap in the forest. Thus disturbance to the site (soil compaction, tree-felling, etc.) was almost completely avoided. This crane can reach heights up to $37 \mathrm{~m}$ over a distance of $30 \mathrm{~m}$. Hence it can be used to sample an area of $60 \mathrm{~m}$ in diameter ( $\cong 0.3 \mathrm{ha}$ ). Within this area there are 13 beech and 14 oak trees. Counting of the leaf-galls of $M$. fagi and $N$. quercusbaccarum on these trees took place on 21 and 22 July 2000 . We divided the tree-crowns into four layers: 0 to 10 $\mathrm{m}, 10$ to $20 \mathrm{~m}, 20$ to $30 \mathrm{~m}$ and the top of the canopy $(>30 \mathrm{~m})$ and sampled at random within each of these layers. At each sample site three branches were randomly chosen and the terminal 50 leaves were checked for galls, and the numbers determined. This procedure resulted in 108 samples made up potentially of a total of 324 branches and 16,200 leaves. Since some of the trees lacked foliage at a given layer, the actual numbers of scanned branches and leaves was 255 and 12,750 , respectively.

Since we were not interested in small-scale heterogeneity, that is, differences between single branches, we lumped the data from each sample site and tested for the effects of individual trees and canopy layer on the mean abundance of galls by means of a two-way ANOVA without replication (Sokal \& Rohlfs, 1995). Data were log-transformed prior to analysis; they were tested for normality by the nullklassen test, a test particularly designed for small sample size (Zöfel, 1992), and for homogeneity of variances by the Bartlett-Test.

\section{RESULTS}

On 135 branches (6,750 leaves) of beech we counted a total of 3,413 galls of $M$. fagi, corresponding to a mean infestation rate of 0.51 galls per leaf. There was a markedly higher abundance in the upper layers of the canopy, with approximately $40 \%$ of all galls $(1,628)$ in the upper part of the canopy (>30 m) (Table 1). 2,786 spangle galls of $N$. quercusbaccarum were counted on 120 branches $(6,000$ leaves) of oak. However, at one sample site we counted 1,116 galls. As the maximum number of galls at all the other sample sites was only 151 , we omitted this outlier value from the analysis, which gave a total of 1,670 galls of $N$. quercusbaccarum on 117 branches (5,850 leaves) and a mean infestation rate of 0.29 galls per leaf. There was no obvious trend in abundance with position in the canopy in this species (Table 1).

To achieve a balanced design for the formal testing of tree and layer effects on mean abundance of galls we considered only beeches with foliage at all four canopy heights. The oaks rarely had a low canopy layer $(0-10$ $\mathrm{cm}$ ); for this analysis we used the data for oaks that had the other three layers and omitted that for oaks that lacked foliage in either the $10-20,20-30$ or $>30 \mathrm{~m}$ layer. Data for six beeches and seven oaks met the above criteria and were analysed. ANOVA showed a highly significant tree effect for both $M$. fagi and $N$. quercusbaccarum (Table 2). Due to the low number of each of the oak species (one $Q$. robur, six $Q$. petraea) no formal test of host species preference could be performed. An a posteriori test of differences in the means showed that there were statistically significant differences in the density of $N$. quercus- 
TABLE 2. An ANOVA of mean abundance of galls of Mikiola fagi and Neuroterus quercusbaccarum on Fagus sylvatica and Quercus robur and $Q$. petraea, respectively, at the Swiss Canopy Crane site near Basel. A sample unit is the sum of the number of galls on three branchs.

\begin{tabular}{lcrccc}
\hline Species & Source of variation & d.f. & MS & $F$ & $p$ \\
\hline M. fagi & Tree & 5 & 1.285 & 4.846 & $\mathbf{0 . 0 0 8}$ \\
& Canopy layer & 3 & 0.914 & 3.444 & $\mathbf{0 . 0 4 4}$ \\
& Error & 15 & 0.265 & & \\
N. quer- & Tree & 6 & 5.920 & 6.040 & $\mathbf{0 . 0 0 4}$ \\
cusbac- & Canopy layer & 2 & 0.016 & 0.017 & 0.984 \\
carum & Error & 12 & 0.980 & & \\
\hline \multicolumn{4}{r}{} \\
\end{tabular}

baccarum spangle galls on the $Q$. robur tree and some of the six $Q$. petraea trees. However, there are also significant differences between individual trees of $Q$. petraea (Table 3 ). When ranked by total number of galls divided by the number of layers per tree (including trees lacking one or more of the layers) $Q$. robur and $Q$. petraea occupied distinctly different positions in the list (Table 4). The chance of ranking the two $Q$. robur at the top of a list that contains two $Q$. robur and 11 others, is the reciprocal of $N ! /(N-2)$ !, where $N$ is total list length, and equals $1 /(13 ! / 11 !)=0.006$. Thus, the chance that the two $Q$. robur top the list when every tree has the same a priori probability of "being drawn" is $\mathrm{p}<0.01$. This suggests that $N$. quercusbaccarum shows a considerable preference for $Q$. robur at the SCC site. The possibility that an aggregation results in a spurious preference for a species (that is, trees with a high gall infestation occur together and so do those with low infestation, irrespective of species or genotype) could be excluded by inspecting a map of the trees at the SCC site (Fig. 1): there was no detectable spatial aggregation of oak trees with similar abundances of spangle galls. Formally tested, the distance between neighbouring trees in the ranked list (Table 4) was statistically indistinguishable from the average distance between oak trees in the stand (d.f. $=51, t=0.19,0.9>p>0.5$ ). Thus, differences in gall abundance can be assigned to differences in host attractiveness. Similarly, for $M$. fagi on $F$. sylvatica there were no large-scale aggregations of trees with high or low infestation rates, respectively: there was no significant difference between the average distance between trees and that between trees that are adjacent on a list ranked according to mean number of galls per sample (d.f. $=51, t$ $=0.11, p>0.9$ ).

In addition to the high intertree variability, the canopy layer also exerted a statistically significant effect on $M$. fagi: gall abundance increased with increasing height in the tree crowns. In contrast, no vertical stratification in spangle gall abundance was detected (Table 2).

\section{DISCUSSION}

The SCC was a very efficient way of collecting data in the canopy. Moving from one sample site to the next took only about one minute, thus little time was required for accessing the canopy and most of the time was devoted to counting and identifying species (in addition to the target organisms all other galls and leaf-mines were counted).
TABLE 3. Difference in abundance of galls of Neuroterus quercusbaccarum on seven oaks at the Swiss Canopy Crane site near Basel analysed using Tukey's honestly significance difference following a two-way ANOVA. A sample unit is the sum of the number of galls on three branchs per tree and canopy layer. Mean abundance of galls per tree is the backtransformed average of log-transformed gall abundance in the different canopy layers. Trees sharing a letter $(a, b, c)$ are not statistically different at $\mathrm{p}<0.05$.

\begin{tabular}{llcllll}
\hline Tree & Species & Mean abundance & & & \\
\hline$\# 11$ & Q. robur & 102.5 & $\mathrm{a}$ & & \\
$\# 2$ & Q. petraea & 69.4 & $\mathrm{a}$ & & \\
$\# 7$ & Q. petraea & 44.3 & $\mathrm{a}$ & $\mathrm{b}$ & \\
$\# 3$ & Q. petraea & 26.8 & $\mathrm{a}$ & $\mathrm{b}$ & \\
$\# 1$ & Q. petraea & 26.3 & $\mathrm{a}$ & $\mathrm{b}$ & \\
$\# 4$ & Q. petraea & 3.4 & & $\mathrm{~b}$ & $\mathrm{c}$ \\
$\# 15$ & Q. petraea & 2.9 & & $\mathrm{~b}$ & $\mathrm{c}$ \\
\hline
\end{tabular}

So it was possible to scan almost 13,000 leaves from all parts of the canopy in only one and a half days; we cannot imagine a more efficient method of sampling forest canopies.

Average abundance of galls of $M$. fagi and $N$. quercusbaccarum at the SCC site $(0.51$ and 0.29 galls per leaf, respectively) lies in the range of published data. Skrzypczynska (1993) reported as few as 0.05 galls of $M$. fagi per leaf in a Polish national park. Urban (2000), sampling a mass outbreak of $M$. fagi in the Czech Republic, counted approximately 1.41 galls per leaf. In England, Askew (1962) recorded a density of 0.11 and 0.36 galls of $N$. quercusbaccarum per leaf on young $Q$. robur in two consecutive years.

Askew (1962) described a distinct vertical distribution of spangle galls on $Q$. robur with $N$. quercusbaccarum predominant in the central part of the canopy and $N$. albipes (Schenck, 1863) and N. numismalis (Geoffroy in Fourcroy, 1785) in the lower and upper part of the canopy, respectively, while Ejlersen (1978) found $N$. quercusbaccarum predominant at the top of trees. These studies, however, involved young oaks only. Based on observation rather than formal data acquisition and testing, no spatial zonation of spangle galls was apparent on mature trees (Askew, 1962). Our findings confirm this observation: no vertical zonation of $N$. quercusbaccarum could be detected at the SCC site. For a related species in California, Neuroterus saltatorius (Edwards, 1874), Rosenthal \& Koehler (1971) identified a trend of decreasing gall abundance on $Q$. lobata Née with increasing tree height. However, they do not state whether the maximum height sampled (ca. $13 \mathrm{~m}$ ) corresponded to maximum tree height or was limited by canopy access. As reported by Askew (1962) for mature trees and in this study, Eliason \& Potter (2001) found that the distribution of leaf galls of the cynipid wasp Callirhytis cornigera (Osten Sacken, 1865) throughout the canopy of 20 year old Quercus palustris Muenchhausen (ca. $11 \mathrm{~m}$ tall) did not differ. These findings refute the hypothesis that vertical zonation patterns are expected to occur regularly "because of the weak flying capacities of 
TABLE 4. Q. robur and Q. petraea trees at the site of the Swiss Canopy Crane ranked by mean number of galls per canopy layer sampled. Tree \#6 was regarded as an outlier and was omitted from the analysis (see Results).

\begin{tabular}{|c|c|c|c|c|c|}
\hline \multirow[t]{2}{*}{ Tree Species } & \multicolumn{4}{|c|}{ Layers represented } & \multirow{2}{*}{$\begin{array}{c}\text { Mean } \\
\text { number of } \\
\text { galls }\end{array}$} \\
\hline & $0-10 \mathrm{~m}$ & $10-20 \mathrm{~m}$ & $20-30 \mathrm{~m}$ & $>30 \mathrm{~m}$ & \\
\hline \#11 Q. robur & & $x$ & $x$ & $x$ & 109.0 \\
\hline \#8 Q. robur & $x$ & $x$ & & $x$ & 85.0 \\
\hline Q. petraea & & $x$ & $\times$ & $x$ & 77.0 \\
\hline Q. petraea & & $x$ & & $x$ & 56.5 \\
\hline \#7 Q. petraea & & $x$ & $x$ & $x$ & 50.3 \\
\hline \#13 Q. petraea & $x$ & $x$ & & $x$ & 34.7 \\
\hline \#3 Q. petraea & & $x$ & $x$ & $x$ & 33.3 \\
\hline \#1 Q. petraea & & $x$ & $x$ & $\times$ & 31.7 \\
\hline \#12 Q. petraea & & & $x$ & $\times$ & 12.5 \\
\hline$\# 4 \quad$ Q. petraea & $x$ & $x$ & $x$ & $x$ & 9.0 \\
\hline \#15 Q. petraea & & $x$ & $x$ & $x$ & 8.7 \\
\hline \#10 Q. petraea & $x$ & $x$ & & $x$ & 6.0 \\
\hline \#14 Q. petraea & $x$ & $x$ & & & 0.0 \\
\hline
\end{tabular}

the gall wasps not allowing them to fly as high as the mature oak branches" (Hough, 1953).

The between-tree distribution of spangle galls of $N$. quercusbaccarum at the SCC-site accords with the findings of various authors who recorded an aggregated distribution of cynipid galls between oak trees (Askew, 1962; Rosenthal \& Koehler, 1971; Hails \& Crawley, 1992; Eliason \& Potter, 2001). Askew (1962) reported that sexual females, which emerged from currant galls on catkins of trees outside the plantation he studied, returned to the plantation and chose the same trees as the sexual females the previous year. Also Rosenthal \& Koehler (1971) stated that the "greatest success in collecting any one species of cynipid gall wasp was achieved by returning to the same tree where its galls had been numerous in previous years". The significant differences in spangle gall abundance between individual oak trees at the SCC site similarly suggest within-species as well as between-species host preferences in N. quercusbaccarum. The limited dispersal ability of galls wasps has been stresses repeatedly (Hough, 1953; Askew, 1984; Eliason $\&$ Potter, 2001). However, the pronounced host choice and colonization of the entire canopy by the adults that emerge from the forest-floor indicates that $N$. quercusbaccarum has effective dispersal capabilities. We doubt this could be achieved by passive transport on air currents. Presumably its locomotory activity is higher before it encounters a suitable host than it is on a host plant.

The impact of host genotype on oviposition and/or performance of gall-formers has received increasing attention over the last few years (e.g., Rossi \& Stiling, 1998; Miller \& Weis, 1999; Cronin \& Abrahamson, 2001) and budburst phenology is suggested as a key factor determining intertree distribution of galls (phenological synchrony hypothesis). It predicts that close synchrony between bud-burst and adult emergence or egg-hatch is important for many gall-inducing insects, particularly those that oviposit before leaf flush. Trees with either slower or faster bud development may escape the attack and, thus, the "windows of vulnerability" (Eliason \& Potter, 2000) are regarded as a major source of variability in suitability between trees (Askew, 1962; Wool \& Burstein, 1992). However, for the cynipid C. cornigera on $Q$. palustris, Eliason \& Potter (2000) found only equivocal support for this hypothesis, with contradictory results in consecutive years. Rosenthal \& Koehler (1971) also found no effect of time of bud opening on spangle galls of $N$. saltatorius. Similarly, in our study tree phenology did not appear to account significantly for the distribution of spangle galls of $N$. quercusbaccarum among trees. No phenological data are available for spring 2000, but in spring 2001 there was no visible difference in time of budburst and unfolding of leaves (trees were inspected every second or third day) between the two oak species: buds of $Q$. petraea opened between 24 and 30 April, and of $Q$. robur on 27 April; leaves were completely unfolded on $Q$. petraea between 27 April and 4 May, and on $Q$. robur on 2 May (S. Pepin, pers. comm.). Irrespective of oak species, there is a only weak and nearly significant correlation between mean gall density per sample site per tree in 2000 (Table 4) and date of leaf unfolding in 2001 ( $\left.r_{\mathrm{S}}=0.53 ; p=0.066\right)$, which leaves most of the variance in spangle gall density unaccounted for. Assuming that the phenology of a single tree does not vary from year to year, this is only weak evidence for the phenological synchrony hypothesis. As pointed out above, N. quercusbaccarum probably has higher dispersal powers than previously assumed, therefore the demic adaptation hypothesis (successive generations of sessile or endophagous species with limited dispersal potential may form localised populations with restricted gene flow and greater host specialisation) (Hanks \& Denno, 1994) is unlikely to account for intertree distribution. Eliason \& Potter (2000) found evidence for localised populations in C. cornigera, but this species completes its entire lifecycle in the canopy and the trees studied were planted in lines and spaced $10 \mathrm{~m}$ apart without canopy contact, whereas $N$. quercusbaccarum overwinters on the ground and the stand at the SCC site is a mature forest with a closed canopy.

$M$. fagi, in contrast to $N$. quercusbaccarum, showed a distinct vertical zonation in the canopy. The statement that its galls are more abundant in lower parts of treecrowns (Skuhravý \& Skuhravá, 1996) could not be confirmed at the SCC site. The opposite was true: the higher in the canopy the larger the numbers of galls of $M$. fagi per sampling-unit (150 terminal leaves on three branches). Further, between-tree differences were pronounced. There is a large variability, for example, in leaf biometry between single beech trees (Körner \& Pepin, pers. comm.), but no assignment to specific genotypes has been made so far. We observed, that in the field high gall abundance occurred in those parts of tree-crowns that were most exposed to light. This was, clearly, true for the 


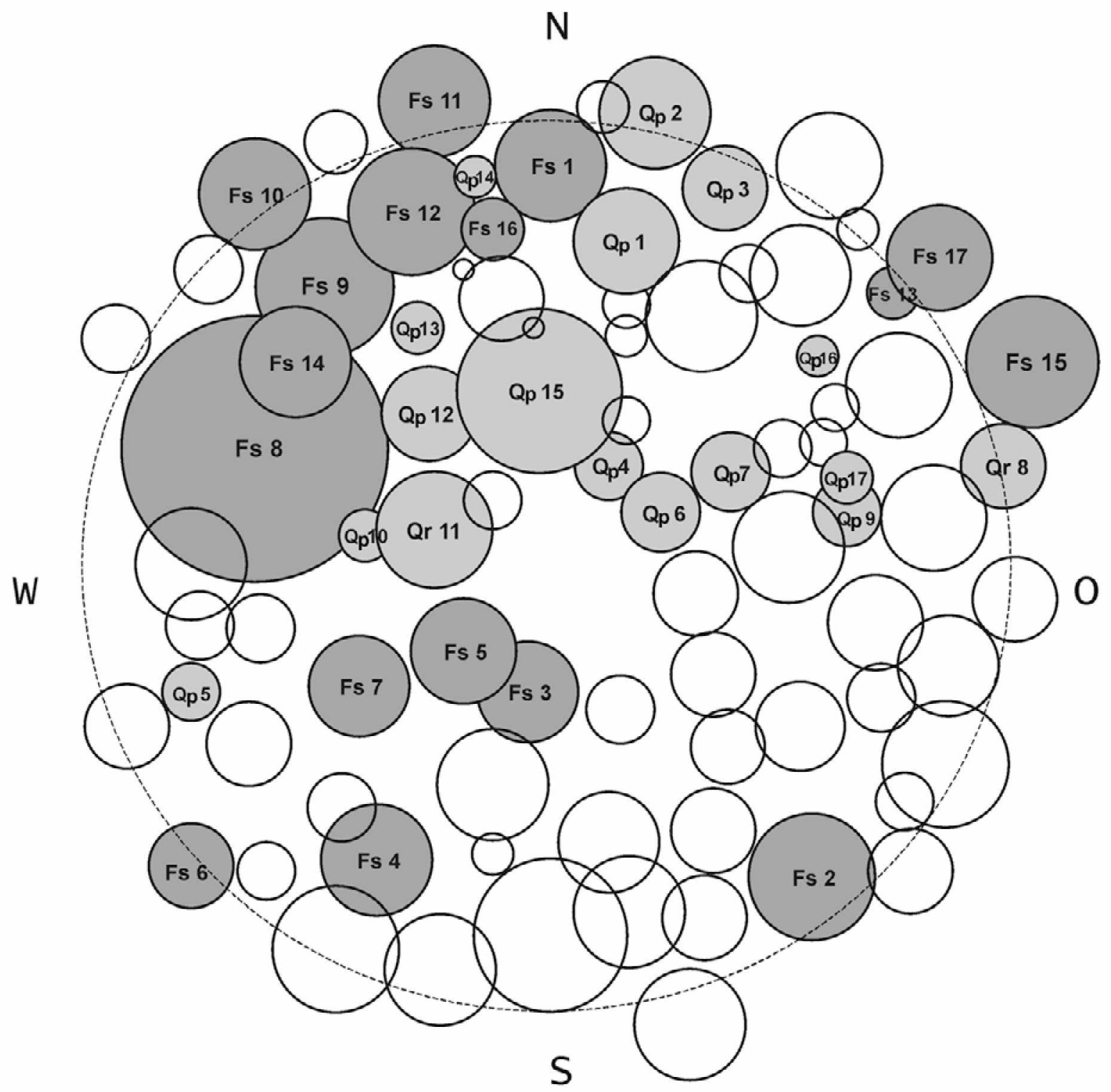

Fig 1. Map of the SCC site near Basel, Switzerland. The dotted circle is the operational area of the crane (diameter $60 \mathrm{~m}$ ), the small circles are vertical projections of the tree crowns: F. sylvatica trees (dark grey) are numbered from Fs 1 to Fs 17 (trees Fs 11 , 13,15 and 17 were not included in the sampling programme due to their small size or only partial accessibility); $Q$. robur and $Q$. petraea (light grey) trees are abbreviated with Qr and Qp and numbered from 1 to 17 (trees 5,16 and 17 were too small to include in the sampling programme). All other trees are shown as empty circles.

top layer of the canopy $(>30 \mathrm{~m})$ but held also for places in lower canopy levels when neighbouring trees were small enough to allow similar light conditions. This corresponds to the observations of K.-H. Lampe (unpublished data) who using a fire-brigade's ladder found the largest gall-numbers in those parts of tree-crowns exposed to direct sunlight. It is well known that sun and shade leaves have very distinct and different morphologies and biochemical and functional properties (for example, number of layers in the palisade parenchyma, chlorophyll $a / b$ ratio or rate of respiration) (Larcher, 1995). However, since oviposition by $M$. fagi occurs early in the year, before bud-opening (Skuhravá \& Skuhravý, 1973), microclimatic preferences might be more important in deter- mining which part of a tree-crown is selected for egglaying. In any case, the speculation that the vertical distribution pattern of galls of $M$. fagi is due to the weak flying capabilities of the adults (Skuhravý \& Skuhravá, 1996) has to be rejected. We found no indication at the SCC site for a reversed zonation (high abundance on lower branches and vice versa) within the 0-10 m layer, corresponding to the vertical zonation reported by Skuhravý \& Skuhravá (1996). Possibly infestation of the lower canopy of $F$. sylvatica excites attention because of the economic significance of $M$. fagi: heavy infestation of young beeches can lead to growth-inhibition due to loss of leaf area (Honomich1, 1998; Urban, 2000) and is much more 
conspicuous than infestation of the upper canopy of adult trees.

We conclude that a canopy crane is a valuable and highly efficient way of accessing the canopies of mature trees and for monitoring the abundance and distribution patterns of plant-galls. Some distribution patterns of galls recorded from young forests were confirmed, for example, distinct intertree differences in $N$. quercusbaccarum gall density. Other findings were new, for example, the vertical distribution of $N$. quercusbaccarum in a mature forest and the distinct inter-tree variation in the density of galls of $M$. fagi. Some findings even contradicted widely held views, for example, the unexpectedly abundant occurrence of $M$. fagi in the top layers of the canopy. The consequences of these distribution patterns for the ecological interactions with the host-plant, inquilines or parasitoids [e.g., canopy-layer specific performance due to plant chemistry, density-dependent parasitism (Hails \& Crawley, 1992; Eliason \& Potter, 2001)] need now to be subjected to further scientific investigation.

ACKNOWLEDGEMENTS. We thank C. Körner (University Basel) for the opportunity to use the SCC facility. S. Pepin (University Basel) steered one of us (M.T.) safely through the canopy and gave all kinds of logistic support at the SCC site. $\mathrm{He}$ also helped in improving the English of this paper and prepared Fig. 1. All his support is gratefully acknowledged.

\section{REFERENCES}

Askew R.R. 1962: The distribution of galls of Neuroterus (Hym.: Cynipidae) on oak. J. Anim. Ecol. 31: 439-455.

ASKEW R.R. 1984: The biology of gall wasps. In: Ananthakrishnan T.N. (ed.): Biology of Gall Insects. Oxford \& IBH Publishing, New Delhi, pp. 223-271.

Bassett Y., Springate N.D., Aberlenc H.P. \& Delvare G. 1997: A review of methods for sampling arthropods in tree canopies. In: Stork N.E., Adis J. \& Didham R.K. (eds): Canopy Arthropods. Chapman \& Hall, London, pp. 27-52.

Brauns A. 1991: Taschenbuch der Waldinsekten. 4th edition, Gustav Fischer, Stuttgart - Jena, 860 pp.

Cronin J.T. \& Abrahamson W.G. 2001: Goldenrod stem galler preference and performance: effects of multiple herbivores and plant genotypes. Oecologia 127: 87-96.

EJleRSEN A. 1978: The spatial distribution of spangle galls (Neuroterus sp.) on oak (Hymenoptera: Cynipidae). Ent. Meddr. 46: $19-25$.

Eliason E.A. \& Potter D.A. 2000: Budburst phenology, plant vigor, and host genotype effects on the leaf-galling generation of Callirhytis cornigera (Hymenoptera: Cynipidae) on pin oak. Environ. Entomol. 29: 1199-1207.

Eliason E.A. \& Potter D.A. 2001: Spatial distribution and parasitism of leaf galls induced by Callirhytis cornigera (Hymenoptera: Cynipidae) on pin oak. Environ. Entomol. 30: 280-287.

HaILS R.S. \& CRAWLeY M.J. 1992: Spatial density dependence in populations of a cynipid gall-former Andricus quercuscalicis. J. Anim. Ecol. 61: 567-583.
Hanks L.M. \& Denno R.F. 1994: Evidence for local adaptation in the armored scale insect Pseudaulacaspis pentagona (Homoptera: Diaspididae). Ecology 75: 2301-2310.

HoNomichl K. 1998: Jacobs/Renner-Biologie und Ökologie der Insekten. 3rd edition, Gustav Fischer, Stuttgart - Jena, 678 pp.

Hough J.S. 1953: Studies on the common spangle gall of oak. III. The importance of the stage in laminar extension of the host leaf. New Phytol. 52: 229-237.

KREBS C.J. 1994: Ecology. 4th edition, HarperCollins College Publishers, New York, $801 \mathrm{pp}$.

Larcher W. 1995: Physiological Plant Ecology. 3rd edition, Springer, Berlin, $506 \mathrm{pp}$.

MANI M.S. 1992: Introduction to cecidology. In: Shorthouse J.D. \& Rohfritsch O. (eds): Biology of Insect-Induced Galls. Oxford University Press, New York-Oxford, pp. 3-7.

MiLleR W.B. \& WeIS A.E. 1999: Adaptation of coyote brush to the abiotic environment and its effects on susceptibility to a gall-making midge. Oikos 84: 199-208.

ROSENTHAL S.S. \& KoEHLER C.S. 1971: Intertree distribution of some cynipid (Hymenoptera) galls on Quercus lobata. Ann. Entomol. Soc. Am. 64: 571-574.

Rossi A.M. \& S TILING P. 1998: The interactions of plant clone and abiotic factors on a gall-making midge. Oecologia 116: $170-176$.

SKRZYYCZYŃsKa M. 1993: Badania owadów i pajęczaków powodujących wyrośla na lisciach buka pospolitego Fagus sylvatica L. w Ojcowskim Parku Narodowym [Studies on insects and mites causing galls on the leaves of Fagus sylvatica L. in the Ojców National Park]. Pol. Pismo Entomol. 62: 133-138. [in Polish, English summary]

SkUHravá M. \& Skunravý V. 1973: Gallmücken und ihre Gallen auf Wildpflanzen. 2nd edition, A. Ziemsen Verlag, Wittenberg Lutherstadt, $118 \mathrm{pp}$.

SkUHravÝ V. \& SkuHravá M. 1996: Betrachtung der Gallmücken (Diptera: Cecidomyiidae) an dominanten Forstgehölzen Eurasiens nach ihrem Schädlichkeitsgrad mit einigen besonderen taxonomischen Problemen. Anz. Schädlingskde. Pflanzenschutz Umweltschutz 69: 56-58.

SOKAL R.R. \& Rohlfs F.J. 1995: Biometry. 3rd edition, W.H. Freeman and Company, New York, $887 \mathrm{pp}$.

STORK N.E., Wright S.J. \& MulkeY S.S. 1997: Craning for a better view: the Canopy Crane Network. Trends Ecol. Evol. 12: $418-420$.

URBAN J. 2000: K bionomii a polymorfismu hálek bejlomorky bukové (Mikiola fagi Htg.) (Diptera: Cecidomyiidae) [Bionomy and polymorphism of galls of the beech leaf gall midge (Mikiola fagi Htg.) (Diptera, Cecidomyiidae)]. J. For. Sci. 46: 114-126. [in Czech, English abstract]

Wool D. \& Burstein M. 1992: Preference, tree resistance, or chance: how to interprete differences in gall density among trees? In: Menken S.B.J., Visser J.H. \& Harrewijn P. (eds): Proceedings of the 8th International Symposium on Insectplant Relationships. Kluwer, Dordrecht, pp. 33-35.

Zöfel P. 1992: Statistik in der Praxis. 3rd edition, Gustav Fischer, Stuttgart, $422 \mathrm{pp}$.

Received July 2, 2001; revised October 9,2001; accepted November 12, 2001 